\title{
Research on Curriculum Reform of College English under the Guidance of Experiencing Teaching Theory
}

\author{
Zhengya Li \\ School of Foreign Language, Xi'an University, Xi'an, 710065, China
}

Keywords: Curriculum reform, College English, Experiencing teaching theory

\begin{abstract}
At present, the experiencing teaching model of college English conforms to the student-centered and task-based teaching concept, and has been widely applied in college English teaching. This paper analyzes the theoretical basis and advantages of experiencing teaching model, and gives the reform directions of college English curriculum based on experiencing teaching theory, including creating life situations, utilizing modern technologies and strengthening teacher-student interactions, to provide some references for the relative researchers.
\end{abstract}

\section{Introduction}

The application of experiential foreign language teaching originates from the practice of teaching reform and has important practical significance. The experiencing teaching method is a teaching method to students as the main body, is in the teaching process, teachers set a specific situation with a certain emotional color, vivid image, guide the participants perception of specific emotions, the participants spontaneously change. Experience teaching students in the learning process of experience and experience, students play the subjective initiative in learning autonomy, learning content will be applied to specific situations, to achieve the combination of theory and practice, to master and apply the knowledge and skills. It is a kind of teaching method to train students' reaction, train students' thinking and practice ability, and train students' ability of using knowledge and skills. Experiential teaching is student-centered, teacher guided as to the study task as the foundation, let the students experience in specific scenarios and rules for the use of the English language, which conforms to the requirements of the times to contemporary applied talents. In addition, the college English teaching reform project revolves around the English discipline construction and personnel training, and puts forward the corresponding training target of college English. To promote the realization of this goal, it is the key to improve teaching methods and improve teaching quality. The experiential teaching method meets the requirements of college English education reform. In the teaching, we should take the student as the main body, the teacher as the guider and the organizer. In the past more than ten years, college English has been trying to solve the problem of time-consuming and inefficient English teaching. Many experts have studied the efficiency of college English teaching from different perspectives, and the teaching of specialized English has also involved. This thesis intends to reform the teaching mode and improve the teaching efficiency of English courses from the perspective of experience.

\section{Theory Basis of Experiencing Teaching Model of College English}

Experiencing teaching comes from experiential learning. Experiential learning comes from a wide range of sources, including pedagogy, psychology and cognitive science. Although the formal study of experiential learning is only about twenty years old, it has been put forward as a kind of theory. It contains many predecessors' ideas. Constructivism can be regarded as the theoretical foundation of experiential teaching. Constructivism, also called structuralism, is an important branch of cognitive theory. Constructivism regards learning as an active and constructive process. In this process, 
students passively accept knowledge did not like traditional meaning, but from their own interests, according to their own cognitive structure and the level of experience to the selection and processing of the knowledge. It emphasizes learner centered learning. Throughout the learning phase, it is always learner centered. Students are the subject of cognition. Teachers can guide learners in a variety of ways, but teachers play a supporting role in helping and promoting students to construct meaning. It can realize this is not the only one teaching method of constructivism, but their common point is to emphasize the creation of scenarios, cooperative learning in the teaching process, and through these links in which learners learn to construct the meaning of learning. Experiential English teaching is based on the above idea. In the process of English learning, students can experience happiness through the process of learning English. It always learns and extends it under an active emotional control. The interaction between emotion and cognition, that is, situated cognition theory, is another theoretical basis of situational experiential teaching. The theory holds that emotion has an important influence on cognitive ability, and cognitive ability in turn can affect emotion. Positive and healthy emotional emotion can improve cognitive ability, but it can play a negative role. At the same time, the improvement and development of cognitive ability is conducive to healthy upward emotions, while the weaker cognitive ability leads to negative and negative emotions, which further affects the functions of all aspects of the body. Situational teaching method by setting up the scene, close to the student life, to attract the interest of students, let students play the initiative and enthusiasm, so as to create a positive and healthy emotion, enjoy the process of learning and teaching experience of pleasure

\section{Advantages of Experiencing Teaching Model of College English}

Situational teaching method in vivid, interesting and vivid in one, can better stimulate students' creativity and imagination, to attract students' interest in learning English, improve the students' language and knowledge transfer ability, training to meet the demands of contemporary society should use and communicative talents. Experiential teaching method can reduce teaching difficulty. The students' English level is different and the students are different. The traditional English teaching method will make the lower ability students feel difficult and lose the students' interest, thus affecting the effect of English learning. Situational teaching method depends on the development of language context and context, language function also needs to be implemented in a certain context and context, this kind of teaching method through the creation of English language learning environment, reduce the difficulty of understanding students, so that students can more easily use the language. Experiential teaching method can improve students' comprehensive ability. The sum of learning English listening and speaking, reading and writing, the ability of the top five, in English teaching, we should cultivate students' comprehensive language ability, students will listen and write only, the most important thing is that can be carried out smoothly, oral communication, free use of English language. Situational teaching method with the help of multimedia network technology provides a learning platform for students, students can follow the tape device to read English materials, imitate to clear and accurate pronunciation and intonation, let students speak fluent English, the past is no longer dumb English. At the same time, experiential teaching creates English situations for students to engage in simulated communicative activities, engage in authentic communication and dialogue, and improve students' English practice and application ability. Experiential teaching method can create English culture atmosphere. In English teaching, teachers can combine teaching materials to introduce students to western countries, local customs and practices and cultural practices, let students experience the cultural differences, such as table manners, wedding etiquette, festival activities, students experience in western countries the historical background, living environment, life style, religion, customs and other content to learn English allusions and idioms. The situational experiential teaching method creates English cultural atmosphere for students and guides them to learn idiomatic English through cultural edification. 


\section{Teaching Reform Directions of Experiencing Teaching Model of College English}

Create Life Situations. Students are irreplaceable subjects of learning activities, and they are also an important part of the complex subjects in educational activities. The highest level of the development of students' subjectivity is that they can actively and consciously plan their own development and become masters of their own development, allowing students to enter the role experience through independent exploration. Create scenarios, including natural scenes and classroom situations. The natural scene refers to the existence of a real-life scenario, with the natural scene, such as students in the school life and material environment, natural scenes and various activities to stimulate students' interest, let the students know the true feelings; learning situation and students' learning tasks, scientific cultural knowledge and skills of scenarios. Use the multimedia equipment, pictures, objects, music creation of the scene, through all kinds of activities and various forms of learning, such as speech, debate competitions, drama performances, rich learning content and expand knowledge. Through classroom practice, the author believes that the experiential teaching model of college English can be divided into four parts: the design of work experience and the design. This stage mainly refers to the class teacher: teachers should choose as far as possible close to the real life in the class, to help students to acquire practical language materials with their own life experiences, experiences linked. This requires teachers to more image teaching, multimedia to create the situation, making the teaching process meaningful. Teachers should ask students to finish some tasks in advance. Teachers and students in the classroom together to watch, to share the experience of each class quasi good material, common understanding of language in different is how to use. It should be noted that this class experience should be shared by both teachers and students. Students according to the preview content, combined with their experience in the stage of experience, through discussion, speech, and other forms of display and strengthen their experience results. The teacher evaluates and feedbacks and develops relevant knowledge. According to the students' performance in the classroom, teachers ask questions in the evaluation, students after class to experience and summarize the language points of application: students in the class to complete the task, can be assisted learning through the Internet or other means.

Utilize Modern Technologies. The use of modern educational technology to enrich the content of teaching, open, closer to students, expand the horizons of teachers and students, so that students in limited space, access to more knowledge. To enable students to master the difference in the use of prepositions, students can guide the production of vehicles through the streets, bridges, forests to express intuitively. Students through hands-on, clear. Also, let the students master the tenses, and they can also be distinguished by animation. Many audio and video materials inside and outside the class enrich the content of teaching, expand the students' knowledge, and help students to explore and experience better. Multimedia technology has been favored by teachers and students for its vivid, interesting, large amount of information and flexible forms. It has been widely used in the classroom. The traditional teaching mode is mainly based on the teacher's interpretation of blackboard writing, and students receive knowledge passively, which is inefficient and ineffective. With the application of modern multimedia technology, students can obtain the latest information from pictures, text, video, sound and other media, and teachers can teach more easily and quickly. Innovative teaching mode should not only flexibly use multimedia network technology, but also carry out individual teaching according to the characteristics of students. The purpose of individuality teaching is to improve students' English learning initiative, to create English learning conditions for students, and to encourage students to study autonomously. To carry out individual teaching, we should do the following four teaching steps: material preparation, situation creation, language use and achievement evaluation. Teachers should prepare appropriate materials for the course content and curriculum objectives, including materials such as pictures, images, sounds and texts. The creation of specific scenarios, including language into multimedia presentations, group activities in the classroom teaching, guide students to use visual, auditory and tactile sensation, sensory experience and participate in the scene, in the context of independent flexible use of language. Finally, the teacher evaluates the learning outcomes in many ways. Nowadays, many universities have set up the 
"College English audio-visual network tutorial", aims to play multimedia network technology, for students to create interest and knowledge of the network platform, to encourage students to carry out autonomous learning activities.

Strengthen Teacher-Student Interactions. The traditional English Teaching in Teachers' teaching, reading, speaking, solution oriented, students mechanically make notes, read and practice, the lack of interaction between teachers and students, students learning English has gradually lost interest in the language is difficult to be used in specific contexts. Situational experiential teaching emphasizes the interaction between teachers and students, which is of vital importance in English teaching and is an important part of the teaching process. Carrying out the interaction between teachers and students helps to cultivate students' interest in learning English, stimulate students' creative thinking, and develop students' psychological functions, to further improve the learning effect and classroom efficiency. Developing the interactive relationship between teachers and students conforms to the requirements of the new era to the new democracy and harmonious teacher-student relationship. Situational teaching in the English teaching process not only requires teachers to change the previous orders and superior image, create conditions for students' English learning, encourage students to participate in the experience of teaching, students are required to take the initiative, independent investment to create the scene, to master English language rules and principles, carry out exchanges and cooperation in learning and life with the teacher in the classroom and extracurricular can. Teachers should be evaluated according to the students' performance and attitude during teaching. This evaluation is different from the previous scores evaluation model, more humane, and make reasonable evaluation according to the characteristics and level of students. Experience teaching method in this context, students in the experience feel that they are the masters of learning, so that every student involved, talk about and his life occupation in English, the situational teaching method can stimulate students' interest, give students a good teaching experience. Practice has proved that the interaction between teachers and students is of great benefit to improve teaching results.

\section{Conclusion}

Experiencing English teaching model pays attention to training and developing students' autonomous learning ability, and fully embodies the concept of teacher-oriented and student-centered education. It not only has constructivism as its theoretical support, but also contains humanistic teaching ideas. The experiencing model of college English still needs to be tested in teaching practice for further improvement.

\section{Acknowledgement}

The research is the result of Teaching Reform Project of Xi'an University in 2016 named Research and Practice on College English Curriculum System Reform (Grant No. JG2016A009)

\section{References}

[1] Pu Qiuju. College English Teaching Based on Experiencing Teaching Approaches [J]. Journal of Beihua University (Social Sciences), 2012, 13(6): 156-158.

[2] Chen Mo. Experiencing Teaching Theory Applied in Graduate English Teaching Reform [J]. Journal of Nanjing University of Aeronautics and Astronautics (Social Sciences), 2013, 15(4): 94-96.

[3] Hong Fang, Chen Xin. Application of Experiencing Teaching to Integrated English Course [J]. Journal of Hefei Normal University, 2013, 31(1): 98-103.

[4] Li Ji. On Situational Experiencing Teaching Method in College English Teaching [J].Overseas English, 2015(8): 67-68+73. 